\title{
Individual dietary diversity is strongly associated with stunting in infants and young children
}

Kenanekaragaman makanan individu berhubungan erat dengan stunting pada bayi dan anak

\author{
Bunga Astria Paramashanti, Yhona Paratmanitya, Marsiswati
}

Department of Nutrition, Faculty of Health Sciences, Universitas Alma Ata, Yogyakarta, Indonesia

\begin{abstract}
Background: The increased nutrient fulfillment is required for optimal growth and development during the first two years of life. Based on WHO, dietary diversity is one of core indicators for assessing diet quality and adequacy. Objective: This study aimed to understand the association between individual dietary diversity and stunting in infants and young children in Sedayu Subdistrict, Bantul District, Yogyakarta, Indonesia. Method: This study used cross-sectional design. It was conducted from February to March 2016 in Sedayu Subdistrict. Subjects were 189 infants and young children aged 6-23 months selected by probability proportional to size sampling technique. Individual dietary diversity was assessed by minimum dietary diversity with the consumption of 4 or more food groups of the total 7 food goups. Data were analyzed by using statistics descriptive, Chi-Square test, and multiple logistic regression. Results: Poor dietary diversity (OR=16,76; 95\%CI: 6,77-41,51) was significantly related with stunting. Other factor associated with stunting was low birth weight (OR=5,12; 95\%CI: 2,11-12,43). In addition, appropiate time of introducing complementary food (OR=0,32; 95\%CI: 0,13-0,75) was a protective factor against stunting. Household economic status acted as an effect modifier and confounding factor between dietary diversity and stunting. Conclusion: Consumption of diverse diet at least 4 food groups reduced the risk of stunting in infants and young children. Efforts should be made to improve dietary diversity in complementary feeding practice.
\end{abstract}

KEYWORDS: dietary diversity; infants and young children; stunting

\begin{abstract}
ABSTRAK
Latar belakang: Peningkatan pemenuhan zat gizi dibutuhkan untuk mencapai pertumbuhan dan perkembangan yang optimal selama dua tahun pertama kehidupan. Berdasarkan WHO, keanekaragaman makanan adalah salah satu indikator inti untuk mengkaji kualitas dan kuantitas diet. Tujuan: Mengetahui hubungan antara keanekaragaman makanan individu dan stunting pada bayi dan anak-anak di Kecamatan Sedayu, Kabupaten Bantul, Yogyakarta, Indonesia. Metode: Desain penelitian cross-sectional yang dilaksanakan pada bulan Februari-Maret 2016 di Kecamatan Sedayu. Subjek adalah bayi dan anak-anak berusia 6-23 bulan yang diambil dengan metode pengambilan sampel probability proportional to size. Keanekaragaman makanan individu diukur berdasarkan minimal keanekaragaman makanan, yaitu konsumsi minimal empat macam golongan makanan. Data dianalisis dengan menggunakan uji deskriptif statistik, Chi-Square, dan regresi logistik ganda. Hasil: Keanekaragaman makanan yang buruk berhubungan signifikan ( $\mathrm{OR}=16,76 ; 95 \% \mathrm{CI}$ : 6,77-41,51) dengan kejadian stunting. Faktor lain yang berhubungan dengan stunting adalah berat badan lahir rendah ( $\mathrm{OR}=5,12 ; 95 \% \mathrm{CI}: 2,11-12,43)$. Selain itu, waktu pemberian MP-ASI yang tepat bertindak sebagai faktor protektif $(\mathrm{OR}=0,32 ; 95 \% \mathrm{CI}$ : 0,13-0,75) kejadian stunting. Status ekonomi rumah tangga bertindak sebagai effect modifier dan faktor pengganggu di antara hubungan keanekaragaman makanan dan stunting. Simpulan: Konsumsi diet yang beragam dengan minimal empat golongan makanan dapat menurunkan risiko stunting pada bayi dan anak-anak. Sejumlah upaya perlu dilakukan untuk meningkatkan keanekaragaman makanan pada MP-ASI.
\end{abstract}

KATA KUNCI: keanekaragaman makanan; bayi; anak-anak; stunting

Corresponding author: Bunga Astria Paramashanti, Department of Nutrition, Faculty of Health Sciences, Universitas Alma Ata, Jalan Ringroad Barat Daya No. 1 Tamantirto, Bantul, Yogyakarta, 55183, Tel: +62 274434 2288, Fax: +62 274434 2269, e-mail: pshanti.bunga@gmail.com 


\section{INTRODUCTION}

Stunting in children has been related with the decreased quality of human capital. Stunting is associated with child's cognitive ability, psychosocial development, social behavior, and obesity status (1-5). In later life, it is also linked with the risk of morbidity and mortality, and lower human development and economic productivity (6).

Globally, stunting affected 162 million of children under-five (7). The prevalence of stunting in young children in Indonesia was 37,2\% in 2013. This prevalence increased slightly from previous survey in 2010 (35.6\%) (8). Compared with WHO global target to reduce stunting by $40 \%$ in 2025 or approximately $3 \%$ per year, Indonesia need a serious effort to reduce stunting problem (7).

Stunting is caused by multisectoral problems. However, it is directly caused by inadequate chronic diet and infections. Dietary factors that were related to stunting included inadequate intake of energy, protein, vitamin B2, vitamin B6, iron, and zinc (9). Furthermore, children who had never received breastfeeding and children who did not continue breastfeeding after one year were also related with higher risk of stunting (10). Nonetheless, breastfeeding alone is not the only factor contributing to stunting in young children. A sufficient diet from complementary food should also be considered (11).

Quantity and quality of diet can be predicted by the diversity of food consumed. Dietary diversity reflects the nutrient quality and adequacy either at household or individual level. Specifically, individual dietary diversity aims to assess nutrient adequacy (12). If the nutritional deficiency happens in a long-term period, it may increase the risk of stunting (13).

Poor quality of complementary food contributed to higher stunting prevalence (10). Otherwise, the consumption of diverse diet has been proven to be associated with stunting reduction $(14,15)$. Based on previous study, food habit with variety protein (such as dairy products, meat products, and legumes) and carbohydrate was linked to decrease the risk of becoming stunting in children (16). However, there was still incosistency in some areas, including Indonesia (17-19). In Indonesia, there was also very few studies assessing the relationship between dietary diversity and stunting. Therefore, a further study is needed to deepen the understanding between those variables. This study aimed to address the association between individual dietary diversity and stunting in young children.

\section{METHODS}

This study used cross-sectional design. It was conducted in February - March 2016 in Sedayu Subdistrict, Bantul District, Daerah Istimewa Yogyakarta. Population was a total of 1.217 young children aged 6-23 months who lived in Sedayu Subdistrict. Based on sample size calculation, we obtained 185 minimum samples. Subjects were selected by using probability proportional to size where Posyandu used as clusters. This study had ethical clearance approval by institutional review board from Universitas Alma Ata Number KE/ AA/I/05/EC/2016. Informed consent was obtained from subjects' parent.

Stunting was defined as anthropometric status of length for age less than -2 SD z-score (20). Child's birth weight was obtained by both interview and looking at Maternal and Child Handbook. Variables such as mother's education, mother's occupation, father's education, father's occupation, household economic income (by income and expenditure), child's history of infections, exclusive breastfeeding, and complementary feeding time were collected by interview with structured questionnaire. The questionnaire had been tested for its validation and reliability.

Food intake data such as energy and protein intake was obtained from mother/caretaker by using 24 hour food recall. For dietary diversity, all food items listed in one day 24 hour food recall were then classified into seven food groups based on World Health Organization (WHO) indicator: 1) Grains, roots, and tubers; 2) Legumes and nuts; 3) Dairy products; 4) Meat, fish, poultry, and liver/organ meats; 5) Eggs; 6) Vitamin A rich fruits and vegetables; and 7) Other fruits and vegetables. We included all food items without minimum quantity, except for condiments (21). Individual dietary diversity score (IDDS) was calculated by the sum of food groups. "Good" category is when subjects consumed more than 4 food groups and "poor" category is when food groups consumed less than 4 . The cut off was chosen because it 
indicated that the child had consumed staple food and at least one animal-source food and one fruit or vegetable on the previous day (22).

Analysis used in this study were descriptive statistics, Chi-Square test, and multiple logistic regression. Final model was made based on stepwise-backward elimination. All the analyses used significance level of 0,05 with STATA 20.0.

\section{RESULTS}

Subjects were 189 young children aged 6-23 months in Sedayu Subdistrict, Bantul District, Daerah
Istimewa Yogyakarta. Subjects were dominated by male children $(59,26 \%)$. Subjects' mother were mostly aged 25-34 years (78,31\%), completed minimum senior high school education $(65,61 \%)$, and did not have any job $(55,56 \%)$. In the other side, most of subjects' father worked as private or public employee, army, police, or entrepreneur $(68,25 \%)$. The prevalence of stunting in young children in this study was $30,69 \%$, whereas low birth weight was 24,34\%. Exclusive breastfeeding coverage only reached half of subjects $(50,26 \%)$. Most of subjects had adequate energy $(56,61 \%)$ and protein $(92,59 \%)$ intake, and good dietary diversity $(62,43 \%)$.

Tabel 1. Bivariate analysis between main variables and stunting

\begin{tabular}{|c|c|c|c|c|c|c|c|}
\hline \multirow{3}{*}{ Variable } & \multicolumn{4}{|c|}{ Stunting } & \multirow{3}{*}{ OR } & \multirow{3}{*}{$\mathbf{p}$} & \multirow{3}{*}{$95 \% \mathrm{CI}$} \\
\hline & \multicolumn{2}{|c|}{ Yes } & \multicolumn{2}{|c|}{ No } & & & \\
\hline & n & $\%$ & $\mathbf{n}$ & $\%$ & & & \\
\hline \multicolumn{8}{|l|}{ Individual dietary diversity } \\
\hline Poor $(<4)$ & 44 & 61,97 & 27 & 38,03 & 12,11 & $0,00 *$ & $5,83-25,10$ \\
\hline Good $(\geq 4)$ & 14 & 11,86 & 104 & 88,14 & 1 & & \\
\hline \multicolumn{8}{|l|}{ Birth weight } \\
\hline $\mathrm{LBW}^{1}(<2500 \mathrm{~g})$ & 28 & 60,87 & 18 & 39,13 & 5,86 & $0,00 *$ & $2,88-11,93$ \\
\hline Normal ( $\geq 2500 \mathrm{~g})$ & 30 & 20,98 & 113 & 79,02 & 1 & & \\
\hline \multicolumn{8}{|l|}{ Exclusive breastfeeding } \\
\hline Yes & 27 & 28,42 & 68 & 71,58 & 0,81 & 0,50 & $0,44-1,49$ \\
\hline No & 31 & 32,98 & 63 & 67,02 & 1 & & \\
\hline \multicolumn{8}{|l|}{ Complementary feeding time } \\
\hline Appropiate (6 months) & 15 & 18,29 & 67 & 81,71 & 0,33 & $0,00 *$ & $0,17-0,65$ \\
\hline Not appropiate $(<$ or $>6$ months $)$ & 43 & 40,19 & 64 & 59,81 & 1 & & \\
\hline \multicolumn{8}{|l|}{ Energy from complementary food } \\
\hline Adequate & 27 & 25,23 & 80 & 74,77 & 0,56 & 0,06 & $0,30-1,03$ \\
\hline Inadequate & 31 & 37,80 & 51 & 62,20 & 1 & & \\
\hline \multicolumn{8}{|l|}{ Protein from complementary food } \\
\hline Adequate & 54 & 30,86 & 121 & 69,14 & 1,12 & 0,86 & $0,35-3,51$ \\
\hline Inadequate & 4 & 28,57 & 10 & 71,43 & 1 & & \\
\hline \multicolumn{8}{|l|}{ Infection diseases } \\
\hline Yes & 6 & 18,18 & 27 & 81,82 & 0,44 & 0,09 & $0,18-1,12$ \\
\hline No & 52 & 33,33 & 104 & 66,67 & 1 & & \\
\hline \multicolumn{8}{|l|}{ Household economic status } \\
\hline \multicolumn{8}{|l|}{ By income } \\
\hline Low & 13 & 28,89 & 32 & 71,11 & 1 & & \\
\hline Middle & 25 & 31,65 & 54 & 68,35 & 1,18 & 0,68 & $0,54-2,61$ \\
\hline High & 20 & 30,77 & 45 & 69,23 & 1,10 & 0,83 & $0,48-2,49$ \\
\hline \multicolumn{8}{|l|}{ By expenditure } \\
\hline Low & 17 & 28,33 & 43 & 71,67 & 1 & & \\
\hline Middle & 16 & 24,62 & 49 & 75,38 & 0,83 & 0,64 & $0,37-1,82$ \\
\hline High & 25 & 39,06 & 39 & 60,94 & 1,62 & 0,21 & $0,77-3,42$ \\
\hline
\end{tabular}

${ }^{1} \mathrm{LBW}=$ low birth weight 
Table 2. Multivariate analysis of factors associated with stunting

\begin{tabular}{lccc}
\hline \multicolumn{1}{c}{ Variable } & OR & p & $\mathbf{9 5 \%}$ CI \\
\hline $\begin{array}{l}\text { Individual dietary diversity } \\
\quad \text { Poor }(<4)\end{array}$ & 16,76 & $0,00^{*}$ & $6,77-41,51$ \\
$\quad$ Good $(\geq 4)$ & 1 & & \\
Birth weight & & & \\
$\quad$ LBW $(<2500 \mathrm{~g})$ & 5,12 & $0,00^{*}$ & $2,11-12,43$ \\
$\quad$ Normal $(\geq 2500$ g) & 1 & & \\
Complementary feeding time & & & \\
$\quad$ Appropiate $(6$ months $)$ & 0,32 & $0,01^{*}$ & $0,13-0,75$ \\
$\quad$ Not appropiate $(<$ or $>6$ months $)$ & 1 & & \\
$*=$ & & &
\end{tabular}

Tabel 3. Stratification analysis between individual dietary diversity and stunting based on household economic status

\begin{tabular}{|c|c|c|c|c|c|c|c|c|}
\hline \multirow{3}{*}{ Stratum } & \multirow{3}{*}{$\begin{array}{c}\text { Individual } \\
\text { dietary diversity }\end{array}$} & \multicolumn{4}{|c|}{ Stunting } & \multirow{3}{*}{ OR } & \multirow{3}{*}{$\mathbf{p}$} & \multirow{3}{*}{$95 \% \mathrm{CI}$} \\
\hline & & \multicolumn{2}{|c|}{ Yes } & \multicolumn{2}{|c|}{ No } & & & \\
\hline & & $\mathbf{n}$ & $\%$ & $\mathbf{n}$ & $\%$ & & & \\
\hline \multicolumn{9}{|c|}{ Household economic status (by expenditure) } \\
\hline \multirow{2}{*}{ Low } & Poor $(<4)$ & 16 & 59,26 & 11 & 40,74 & 46,55 & $0,00 *$ & $2,99-723,76$ \\
\hline & Good $(\geq 4)$ & 1 & 3,03 & 32 & 96,97 & 1 & & \\
\hline \multirow{2}{*}{ Middle } & Poor $(<4)$ & 12 & 50,00 & 12 & 50,00 & 9,25 & $0,00^{*}$ & $2,11-40,39$ \\
\hline & Good $(\geq 4)$ & 4 & 9,76 & 37 & 90,24 & 1 & & \\
\hline \multirow{2}{*}{ High } & Poor $(<4)$ & 16 & 80,00 & 4 & 20,00 & 15,56 & $0,00^{*}$ & $3,10-77,89$ \\
\hline & Good $(\geq 4)$ & 9 & 20,46 & 35 & 79,54 & 1 & & \\
\hline Crude OR & & & & & & 12,11 & $0,00^{*}$ & $5,83-25,10$ \\
\hline MH OR & & & & & & 16,25 & $0,00^{*}$ & $6,00-43,99$ \\
\hline
\end{tabular}

$*=$ significant $(\mathrm{p}<0,05)$

Bivariate analysis results showed that there were several variables that had a significant association with stunting, such as poor dietary diversity $(\mathrm{OR}=5,22$; 95\%CI: 3,09-8,83), low birth weight ( $\mathrm{OR}=2,90$; 95\% $\mathrm{CI}$ : 1,96-4,30), and appropiate time of complementary feeding (OR=0,46; 95\%CI: 1,96-4,30) (Table 1). On the other hand, exclusive breastfeeding, energy and protein adequacy from complementary feeding, infection diseases, and household economic status were not related to stunting.

Multivariate analysis showed that stunting was strongly related with individual dietary diversity in young children. Subjects who had poor dietary diversity or consumption of food groups less than four were associated with 16,76 times higher chance of becoming stunting (95\%CI: 6,77-41,51) than children who had good dietary diversity. Other variables that significantly associated with stunting including low birth weight
$(\mathrm{OR}=5,12 ; 95 \% \mathrm{CI}: 2,11-12,43)$ and appropiate time of complementary feeding ( $\mathrm{OR}=0,32 ; 95 \% \mathrm{CI}: 0,13-0,75)$. Table 2 below showed a final model after applying stepwise-backward elimination.

Stratification analysis was conducted based on household economic status (by expenditure) to see whether there was an effect modification in the association between individual dietary diversity and stunting. The variable of housheold economic status was considered because several studies showed it was related to both dietary diversity and stunting $(12,16,23)$. Based on Table 3, there was quite different odd ratios obtained accross household economic levels. The highest odd ratio score was from low economic status $(\mathrm{OR}=46,55 ; 95 \% \mathrm{CI}$ : $2,99-723,76)$. It showed that household economic status (by expenditure) was an effect modifier. In addition, there was also a significant difference between crude and mantel-haenzel odd ratios indicating that household 
economic status (by expenditure) was a confounding factor in the relationship between individual dietary diversity and stunting.

\section{DISCUSSION}

\section{Individual dietary diversity and stunting}

Sedayu Subdistrict reflected semi-urban living area that the prevalence of stunting was still high $(30,69 \%)$. This prevalence was slightly below stunting prevalence in Indonesia (37,2\%) (8). Nutrient adequacy, such as energy and protein intake, was not a problem in this study and was not related with stunting in subjects. Exclusive breastfeeding coverage might be low $(50,6 \%)$ but it was not associated with stunting. A previous study using national secondary data in Indonesia also did not result in significant association between exclusive breastfeeding and stunting (22). Thus, stunting problem in young children may not be caused by nutrient adequacy only, either from exclusive breastfeeding or complementary feeding. The quality of complementary feeding should also be considered.

Result in this study showed that individual dietary diversiry score (IDDS) was strongly associated with stunting in infants and young children aged 6-23 months. Infants and young children who consumed low dietary diversity (or less than 4 food groups) had 16,67 higher chance to become stunting compared to those who had high dietary diversity ( 4 or more food groups). This result was in accordance with previous studies in Cambodia and Bangladesh $(15,16)$. Diet quality need to be considered for assessing infant and young child feeding practice. Nutritional quality of the diet can be reflected by IDDS (13).

The 7 food groups in WHO minimum dietary diversity was used as it links to the diet quality both in breastfed and non-breastfed children. Dietary diversity is related to the consumption of food groups from at least one animal source and one fruit or vegetable source, besides staple food (22). In addition, it indicates individual intake of calorie in a previous day and adequate nutrition for infant and young children $(24,25)$. Thus, prolonged poor dietary diversity may contribute to lower quality of complementary food and inadequate calorie intake, then combined with other risk factors, it will increase the chance of infants and young children becoming stunting.

Although household economic status, both by income and by expenditure, did not show a significant relationship with stunting in bivariate and multivariate analyses, the result from stratification analysis showed a unique trend between household economic (by expenditure) levels. We stratified the association between dietary diversity and stunting based on economic status. Every level of household economic status gave quite different odd ratios indicating that there was a variation in the association between individual dietary diversity and stunting among economis status levels.

Individual dietary diversity was significantly related with stunting especially at the lowest level of economic status. This result proved that dietary diversity was a strong predictor of stunting, especially in young children with poor economic status. A study in Cambodia also showed that dietary diversity was a protective factor against stunting children after adjusting for socioeconomic factors (15). Dietary diversity can take a snapshot of household purchasing power for a variary of food (14). It has been stated that dietary diversity can also be an indicator to measure household food security, both in rural and urban living areas, and across different seasons (26). There was also an evidence showing that food consumption with minimum four food groups consumed was higher in food secure population than in food insecure population (18). Although this study did not collect food security data, our stratification analysis indicated that food security might act as a mediating factor between housheold economic status and dietary diversity. In conclusion, dietary diversity can be used as an indicator to reflect food security status within households.

\section{Other factors associated with stunting}

Low birth weight was associated with stunting significantly. Infants and young children who had low birth weight history (less than $2500 \mathrm{~g}$ ) were at risk to become stunting 5,12 times higher than those who had normal birth weight. Other studies also showed similar results $(12,24,25,27)$. This result undelined the evidence that stunting is a chronic condition. It can be caused 
by previous nutritional status since pregnancy or even preconception period. This intergenerational malnutrition problem was indicated by the history of low birth weight or having short stature mother (12). Short stature mothers who did not improve their nutritional status would have the same inadequate nutritional exposure during pregnancy, thus giving birth to low birth weight babies. Low birth weight babies who failed to catch up growth during the first two life of their life would have higher risk of stunting.

Inappropiate time to introduce complementary feeding was related with higher risk of stunting. Infants and young children who received complementary food too early (before 6 months) or late (more than 6 months) had 3,13 times higher to become stunting than those who receive complementary food timely (at 6 months). Besides ensuring the adequacy of complementary food, the time to introduce the first complementary food to infants is important to reduce stunting (28-30).

Subjects in this study who received complementary food timely were only $43,39 \%$. This proportion was categorized as poor based on WHO rating on timely complementary feeding. World Health Organization (WHO) stated that one of appropiate ways to give complementary feeding is to introduce food timely. It means that food have to be given to child when exclusive breastfeeding cannot fulfill energy and nutrients (31). Infants and young children who had complementary food too early may have higher risk to contamination exposures and lower quality of nutrient intake. Moreover, late introduction of complementary food will increase inadequacy of nutrient intakes due to prolonged exclusive breastfeeding. Therefore, it is important to provide complementary food that is timely, adequate and safe for infants and young children.

\section{Stengths and limitations}

There very few studies assessing the relationship between dietary diversity and stunting in Indonesia. This study may contribute to fill the gap in the stunting problem related to the quality of complementary food. It gives a new sight on how individual dietary diversity gives an impact on stunting in young children. However, this study used cross-sectional design so it could not provide causal- effect relationship between two variables. In addition, food consumption data was obtained by $24 \mathrm{hr}$ food recall so it did not reflect habitual intake of subjects.

\section{CONCLUSION}

Based on the result of this study, individual dietary diversity score can be used as an indicator of dietary quality from complementary feeding in infants and young children. It is also a strong predictor of stunting. The relationship between dietary diversity and stunting does not differ across household economic level. However, dietary diversity has the strongest association with stunting especially in the poorest economic status. This evidence supports the previous theory that dietary diversity may be related with household food security.

Consumption of diverse diet with minimum four food groups may improve the quality of complementary food. Dietary education would be the most effective strategy to deliver messages about infant and young child feeding practices, especially on dietary diversity. Exception should be made in food-insecure population which is to provide enriched complementary feeding products in addition to education and couselling. Finally, efforts have to be done in order to support dietary diversification such as promotion of local food production, home gardening, small-animal production, and dietary modification to provide diverse diet within households.

\section{CONFLICTS OF INTERESTS}

The author states no conflict of interest.

\section{REFERENCES}

1. Crookston BT, Dearden KA, Alder SC, Porucznik CA, Stanford JB, Penny ME, et al. Impact of early and concurrent stunting on cognition. Matern Child Nutr 2011;397-409.

2. Casale D, Desmond C, Richter L. The association between stunting and psychosocial development among preschool children: a study using the South African Birth to Twenty cohort data. Child Care Health Dev [series online] 2014 Nov [cited 2016 Nov 4];40(6):900-10. Available from: URL: http://www.ncbi.nlm.nih.gov/pubmed/24807234 
3. Liu J, Raine A. Nutritional status and social behavior in preschool children : the mediating effects of neurocognitive functioning. Matern Child Nutr 2016;1-15.

4. Symington EA, Diet M, Gericke GJ, Diet M, Nel JH, Labadarios D, et al. The relationship between stunting and overweight among children from South Africa : Secondary analysis of the National Food Consumption Survey Fortification Baseline I. S Afr Med J 2015;106(1):65-9.

5. Navti LK, Ferrari U, Tange E, Parhofer KG, Pozza SB-D. Height-obesity relationship in school children in Sub-Saharan Africa: results of a cross-sectional study in Cameroon. BMC Res Notes 2015;8:98.

6. Prendergast AJ, Humphrey JH. The stunting syndrome in developing countries. Paediatr Int Child Health [series online] 2014 Nov [cited 2016 Nov 4];34(4):250-65. Available from: URL: http://www.pubmedcentral.nih. gov/articlerender.fcgi?artid $=4232245 \&$ tool $=$ pmcentre $\&$. rendertype $=$ abstract

7. World Health Organization (WHO). WHA global nutrition target 2025: stunting policy brief. Geneva: World Health Organization; 2010.

8. Kementrian Kesehatan RI. Riset kesehatan dasar 2013. Jakarta: Kementerian Kesehatan RI; 2013.

9. World Health Organization (WHO). Proposed global targets for maternal, infant and young child nutrition. [series online] 2012 [cited 2016 Nov 4]. Available from: URL: http://www.who.int/nutrition/events/2012 proposed_globaltargets_backgroundpaper.pdf

10. Hidayati L, Hadi H, Kumara A. Kekurangan energi dan zat gizi merupakan faktor risiko kejadian stunted pada anak usia 1-3 tahun yang tinggal di wilayah kumuh perkotaan Surakarta. Jurnal Kesehatan 2010;3(1):89-104.

11. Zhou H, Wang XL, Ye F, Zeng XL, Wang Y. Relationship between child feeding practices and malnutrition in 7 remote and poor counties, PR China. Asia Pac J Clin Nutr. 2012;21(2):234-40.

12. Paramashanti BA, Hadi H, Gunawan IMA. Pemberian ASI eksklusif tidak berhubungan dengan stunting pada anak usia 6 - 23 bulan di Indonesia. Jurnal Gizi dan Dietetik Indonesia 2015;(1):162-74.

13. Kennedy GL, Ballard T, Dop M. Guidelines for measuring household and individual dietary diversity. Rome: Food and Agriculture Organization; 2010.

14. Ikeda N, Irie Y, Shibuya K. Determinants of reduced child stunting in Cambodia: analysis of pooled data from three demographic and health surveys. Bull World Health Organ [series online] 2013 [cited 2016 Nov 4];91:341-9. Available from: URL: http://www.pubmedcentral.nih.gov/articlerender.f cgi?artid=3646343\& tool=pmcentrez\&rendertype $=$ abstract

15. Darapheak C, Takano T, Kizuki M, Nakamura K, Seino K. Consumption of animal source foods and dietary diversity reduce stunting in children in Cambodia. Int Arch Med [series online] 2013 [cited 2016 Nov 4];6(1):29. Available from: URL: http://www.pubmedcentral.nih.gov/ articlerender.fcgi? artid $=3720190 \&$ tool $=$ pmcentre $z \&$ rende rtype $=$ abstract

16. Rah JH, Akhter N, Semba RD, de Pee S, Bloem MW, Kraemer K, et al. Low dietary diversity is a predictor of child stunting in rural Bangladesh. Eur J Clin Nutr [series online] 2010 [cited 2016 Nov 4];64(12):1393-8. Available from: URL: http://dx.doi.org/10.1038/ejen.2010.171

17. Esfarjani F, Roustaee R, Mohammadi-Nasrabadi F, Esmaillzadeh A. Major dietary patterns in relation to stunting among children in Tehran, Iran. J Heal Popul Nutr 2013;31(2):202-10.

18. Amugsi DA, Mittelmark MB, Lartey A. Dietary diversity is a predictor of acute malnutrition in rural but not in urban settings: evidence from Ghana. Br J Med Med Res 2014;4(25):4310-24.

19. Muslimatun S, Wiradnyani LA. Dietary diversity, animal source food consumption and linear growth among children aged 1-5 years in Bandung, Indonesia: a longitudinal observational study. Br J Nutr [series online] 2016 [cited 2016 Nov 4];116(Suppl 1):S27-35. Available from: URL: http://www.journals.cambridge.org/abstract S0007114515005395

20. Ocampo-guirindola ML, Garcia-malabad CJ, Valdeabellamaniego MLM, Punzalan SLM. Association between dietary diversity score and nutritional status of filipino children aged 6-23 months. Philipp J Sci 2016;145(1):57-69.

21. WHO Multicentre Growth Reference Study Group. WHO Child Growth Standards based on length / height, weight and age. Acta Paediatr 2006;450:76-85.

22. World Health Organization (WHO). Indicators for assessing infant and young child feeding practices. France: WHO Library Cataloguing-in-Publication Data; 2008.

23. Ruel MT, Menon P. Child feeding practices are associated with child nutritional status in Latin America: innovative uses of the demographic and health surveys. J Nutr 2002;132(6):1180-7.

24. Vitolo MR, Gama CM, Bortolini GA, Campagnolo PDB, Drachler MDL. Some risk factors associated with overweight, stunting and wasting among children under 5 years old. J Pediatr (Rio J) 2008;84(3):251-7.

25. Bove I, Miranda T, Campoy C, Uauy R, Napol M. Stunting, overweight and child development impairment go hand in hand as key problems of early infancy: Uruguayan case. Early Hum Dev [series online] 2012 [cited 2016 Nov 4];88:747-51. Available from: URL: http://dx.doi. org/10.1016/j.earlhumdev.2012.04.002

26. Hoddinott J, Yohannes Y. Dietary diversity as a household food security indicator. [series online] 2002 [cited 2016 
Nov 4]. Available from: URL: http://www.aed.org/Health/ upload/dietarydiversity.pdf

27. Nasution D, Nurdiati DS, Huriyati E. Berat badan lahir rendah (BBLR) dengan kejadian stunting pada anak usia 6-24 bulan. Jurnal Gizi Klinik Indonesia 2014;11(1):31-7.

28. Giugliani ERJ, Victora CG. Complementary feeding. J Pediatr (Rio J) 2000;76(Suppl 3):253-62.

29. Gupta A, Dadhich JP, Faridi MM. Breastfeeding and complementary feeding as a public health intervention for child survival in India. Indian J Pediatr 2010;77:413-8.
30. Khasanah DP, Hadi H, Paramashanti BA. Waktu pemberian makanan pendamping ASI (MP-ASI) berhubungan dengan kejadian stunting anak usia 6-23 bulan di Kecamatan Sedayu. Jurnal Gizi dan Dietetik Indonesia 2016;4(2):105-11.

31. World Health Organization (WHO). Infant and young child nutrition: global strategy on infant and young child feeding. Fifty Fifth World Heal Assem [series online] 2002 [cited 2016 Nov 4];1-18. Available from: URL: http://apps. who. int/gb/archive/pdf_files/WHA55/ea5515.pdf 